
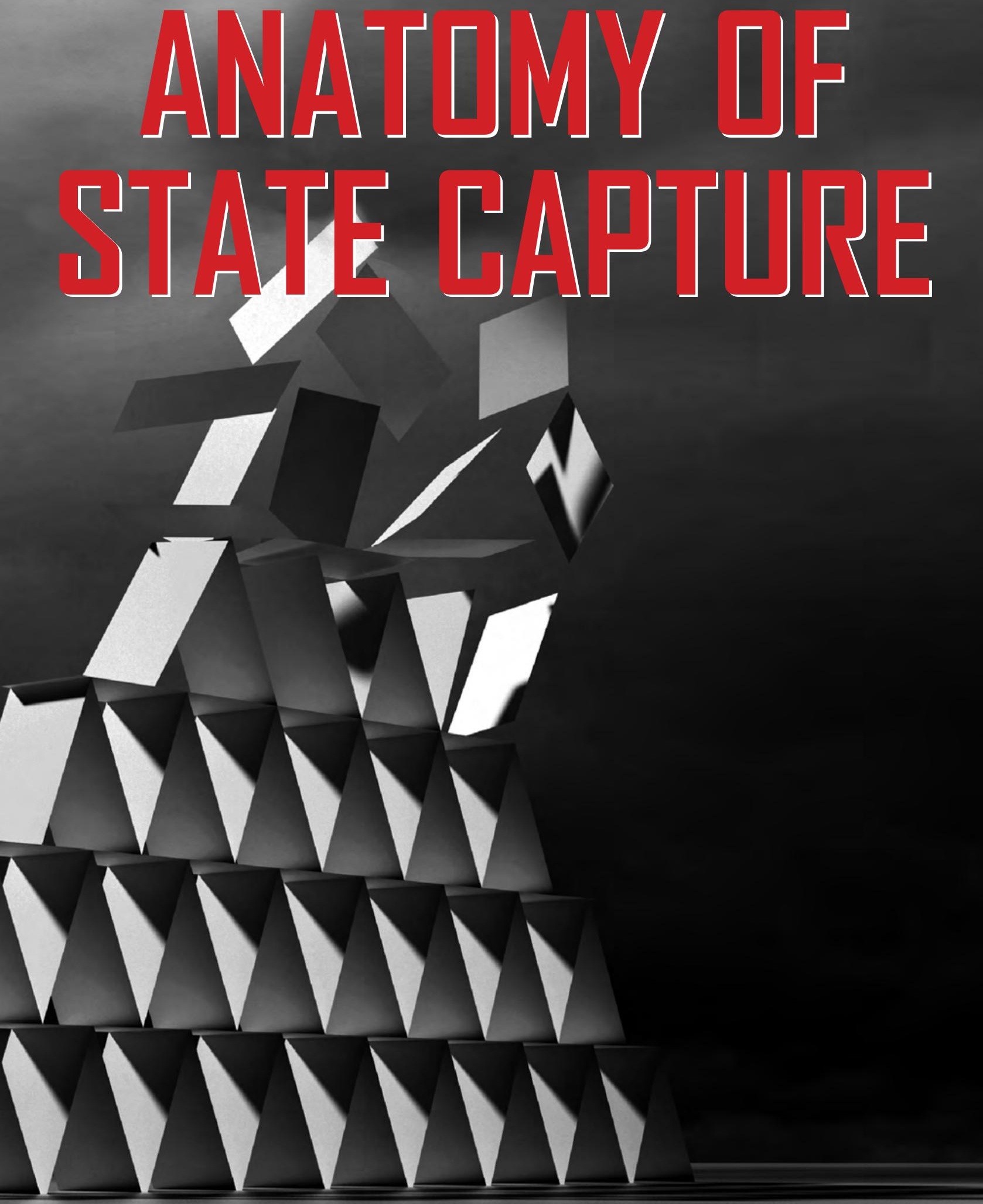

Nina Callaghan, Rabyn Foley and Mark Swilling (EDITuRS) 


\section{BETWEEN LIBERALISATION AND STATE CAPTURE: A DEEPER LOOK AT THE CASE OF ESKOM}

Erica Johnson

Current understanding of the phenomenon of state capture in South Africa highlights it as a focused, political-economic project that lead to the repurposing of governance in SOEs and the eventual decline in their organisational ability to deliver on core institutional mandates. While this definition is apt and powerfully explains recent performance failures, it does not explain why, when malfeasance is removed, these organisations are unable to return to functioning productively.

The contention is that the weakening of state-owned institutions has deeper roots than the recent state capture project. In the case of Eskom, it is proposed that over a length of time, weaknesses in and the manipulation of the governance framework fundamentally led to its fragile state and its inability to withstand malfeasance. Jaglin and Dubresson (2016, p. 6) note that "Eskom's crises are institutional in nature and arise above all from the nature of the relationship between Eskom and the state. The succession of mismatches and readjustments has reached its limits and a fundamental redefinition of the relationship has become critical". It is in fact this succession of mismatches and readjustments that has left the organisation unable to deliver securely on its electricity mandate - presenting an existential threat to the South African economy.

\subsection{BETWEEN THE DE VILLIERS COMMISSION AND THE ZONDO COMMISSION: KEY INFLECTION POINTS IN THE ELECTRICITY SECTOR}

Eskom supplies $90 \%$ of South Africa's electrical energy, providing a critical foundation to the Minerals Energy Complex ${ }^{1}$ (McDonald, 2009, p. 12) - that includes mining, manufacturing and services in urban centres. Statistics SA notes that in 2019 the primary mining and manufacturing sectors made up $21 \%$ of nominal GDP and the urban productive sector $24 \%$ of nominal GDP (Stats SA, 2019). Together, these two

1 Fine and Rustomjee conceptualise in the mid 90s, the notion of Minerals Energy Complex (a set of mining activities and related industrial and manufacturing activities) that lie at the core of the South African economy, not only by virtue of their weight in economic activity, but also 'through their determining role in the rest of the economy (Fine \& Rustomjee, 1996, p. 5). 15 years later, McDonald in the mid 00s extends this definition to a Minerals Energy Complex plus, acknowledging the growth of an urban producer services sector, in addition 
sectors account for $35.5 \%$ of employment (Stats SA, 2019). Given this weight, the potential disruption to South Africa's economy is clear if the risk posed by unreliable and unaffordable electricity supply is not addressed effectively.

The key inflection points in the electricity industry in the 35 years between the De Villiers Commission and the current Commission of Inquiry into State Capture (hereinafter referred to as 'the Zondo Commission') are presented in Figures 5.1 and 5.2. It highlights from an internal organisational perspective which events fundamentally weakened Eskom and from which it has not recovered.

The De Villiers Commission was established in 1983 to "examine Escom and electricity pricing throughout South Africa" (Conradie \& Messerschmidt, 2000, p. 244). Its farreaching recommendations included that the public-interest limitation on Escom be lifted, the transfer of ministerial accountability be shifted from minerals and energy to public enterprises, the establishment of a two-tier governance structure, and that the utility operate on a more commercial basis, including paying taxes and dividends to its shareholder, the state. The Zondo Commission was established in 2018 to examine State Capture, Corruption and Fraud in the Public Sector and was guided by the Public Protector's report on SOEs, including Eskom, titled State of Capture. The Zondo Commission has not yet concluded its work at the time of this writing.

Following the De Villiers Commission's recommendation, a new techno-political regime was implemented between 1987 and 2001 with Eskom's incorporation ${ }^{2}$ as a company and the establishment of the National Energy Regulator (NER) - later renamed the National Energy Regulator of South Africa (NERSA). ${ }^{3}$ The period was characterised by a drive for internal modernisation and adaptation to the political changes in the country.

to the traditional mineral extraction and processing as the productive nucleus of the South African economy (McDonald, 2009, p. 12). McDonald notes that "Producer services firms are those that service the centralization requirements of globalized manufacturing and industrial companies, including mining. Most notable amongst these are accounting, law, advertising, corporate travel, security, public relations, management consulting, IT, real estate, storage, data processing and insurance companies" (McDonald, 2009, p. 12).

2 The De Villiers commission's recommendations on changing institutional form and governance culminated in the amendment in 1987 of the Electricity Act (No. 42 of 1922), creating the parastatal Eskom via the Eskom Act (No. 41 of 1987). The commissions' recommendations to become a dividend-paying and tax-paying entity culminated in the Eskom Conversion Act (No. 13 of 2001). Gentle (2009) notes that the change from Escom to Eskom was merely a change in nomenclature, but marked a radical rupture in the nature of South African capitalism, from a form of Keynesian racial capitalism to a neo-liberal state attempting to open new arenas for commodification.

3 In 1995, NER was constituted legally as an independent institution with authority over Eskom, local distributors and state departments. Eberhard (2007) notes it replaced the anomalous position where the Electricity Control Board, established in 1922, had no direct control over 
Within this institutional framework, the rules governing Eskom changed significantly. It went from being self-regulating (in its parastatal phase) to agreeing to price compacts to reduce the real price of electricity by $20 \%$ between 1985 and 2000 . Thereafter, from 2001-2008, it had an adversarial relationship with the regulator, with Eskom initiating an appeal to the Minister of Minerals and Energy as incentive regulation led to a further reduction in the real price of electricity and away from the principle of moving towards cost reflectivity (Eskom, 2003; Joubert, 2015). ${ }^{4}$

The steady increase in demand and the "sweat the assets approach" in the 1990s and 2000s meant higher volumes of coal were required to support the higher generation load factors. The railing and trucking of coal therefore became a viable option to supplement coal supplies at power stations, in addition to coal supplied from tied collieries. In 2003, the critical year when the net generation reserve margin decreased to $15.3 \%$ due to energy demand growth, the corresponding coal purchases increased to 104.4 million tons of coal, 5.5 million tons more than forecast (Eskom, 2003), to support the production requirements and stockpile levels. Road and rail transport also reflected this operational pressure with a total 6.7 million tons being transported in that year; the equivalent of half a power station's annual production.

Recognising the unsustainability of transporting this volume of coal via road and that the full capacity of all power stations would be required in 2006, new coal transport system projects were initiated for the power stations with the most vulnerable logistics chain. This led to a rise in coal costs and became the target of regulatory attention under the rate of return and incentive-based regulatory methodology. In an example of tight revenue oversight and control, the NER in Multi-Year Price Determination 1 (MYPD1) decided to treat future fuel supplies (specifically coal stockpiles) as part of working capital and capped the nominal rate of return on that asset, in addition to disallowing a return on a portion of that stockpile (NERSA, 2006). Financially, this translated in lower expenditure on future fuel supplies. This operational consequence, in addition to the high production requirements across the coal-fleet and an inability to meet planned coal production requirements by the tie collieries, reduced the coal system buffers over a two-year period leading to the eventual collapse in coal security 5 and the January 2008 load-shedding crisis (NERSA, 2008).

municipal electricity undertakings and The Electricity Act of 1987 exempted Eskom from having to obtain a license.

$4 \quad$ Eberhard (2007) notes that despite the NER having developed into one of the more respected independent regulatory institutions in the African continent, it faced huge challenges in terms of building sufficient capacity to regulate Eskom. Eberhard highlights that the creation of new, stable, and competent institutions in developing countries is a formidable task, particularly when there is little tradition and experience of independent regulation.

5 In 2008, NERSA decided that maintaining a minimum of 20 coal stock days across the system would be made an Eskom licence requirement (NERSA, 2008). 


\section{LIVING OFF THE PAST \& NOT How a lack of energy \& initiative}

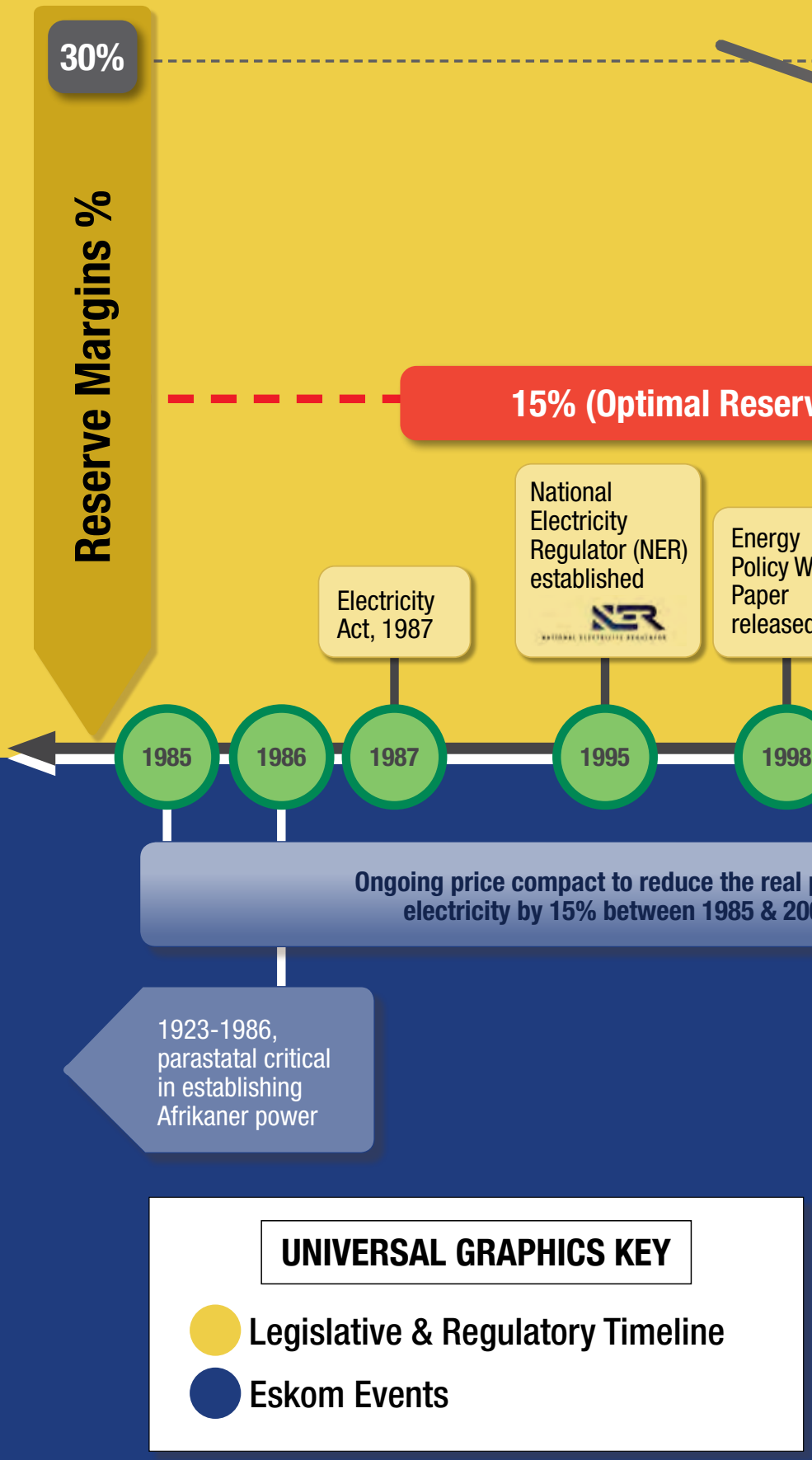




\section{PREPARING FOR THE FUTURE helped push SA into dark times}

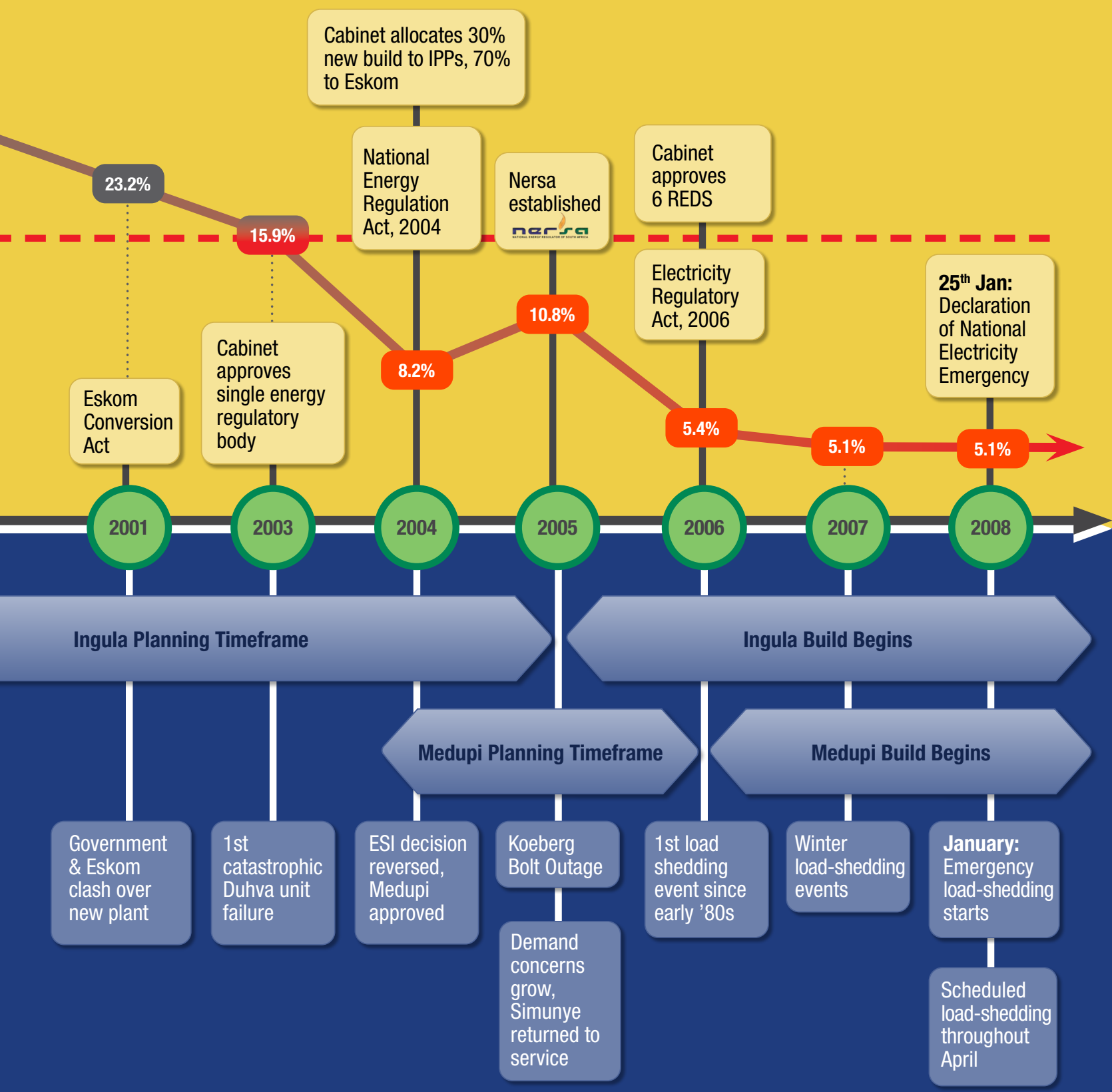


In the period 1999-2004, there had been several prominent engagements between Eskom and policy makers in the Energy Ministry on the need to ensure security of supply by expanding generation capacity and increasing tariffs gradually to ensure access to commercial funding and adjustment to the price path for new generation capacity. In 1999, the decision was taken by the government and the NER to not allow Eskom to start development on the next base-load power station, critical for the country's supply adequacy. This decision was based on the 1998 energy policy which favoured Independent Power Producers. However, there was an inherent contradiction in the policy between liberalising the electricity industry and commodifying electricity while simultaneously requiring cheap, reliable coal-based electricity to maintain the minerals-energy nexus of the economy. Not addressing this contradiction timeously created severe energy insecurity within the next decade, and South Africa is yet to recover from these reverberations. In 2004, the insecurity of the power system became apparent at an operational level, with the first-generation maintenance requests being deferred and all available generation capacity being utilised at high load factors to meet demand. Cabinet reversed the decision preventing Eskom from building the next power station.

From 2005, there was a sharp adjustment that shifted Eskom to an expansion cycle with order placements for three new power station projects (Ingula, Medupi and Kusile). This massive expansion was in addition to the requirement that Eskom maintain peak performance from existing operating plants to meet demand. With support from the shareholder to respond urgently to the energy shortages (Mbeki, 2008), Eskom, with limited skills ${ }^{6}$ and project development capacity, ${ }^{7}$ proceeded with the new build programme and internalised all the mega-project risks (engineering, procurement, construction) to gain traction on the build programme.

This decade, marked by major policy reversals, new governance models, cost reductions and abrupt adjustments in organisational life cycle, culminated in the 2008 declaration of an electricity emergency; a major shock to the economy with the mining and manufacturing sectors bearing the brunt of the power rationing. The emergency became a catalyst for a flurry of activity from the government, with the gazetting of an electricity pricing policy (Department of Minerals and

$6 \quad$ NERSA noted that worldwide demand for scarce skills was impacting on Eskom's need for skilled staff (NERSA, 2008). They noted that Eskom had a high vacancy rate of critical scarce skills at power stations ( 1500 vacancies out of 3200 positions).

7 Paul O'Flaherty reported to the Parliamentary Energy Committee that when Eskom started closing contracts in 2005 on the new build projects, the supplier market was experiencing shortages of material, components and engineering skills (PMG, 2012). 
Energy, 2008), the approval of a shareholder loan of R60bn, government guarantees of R176bn (National Treasury, 2009), significant tariff re-openers approved, promulgation of new generation regulations and a review of the country's energy security initiated via an Integrated Resource Planning process.

The decade following the 2008 emergency declaration was tumultuous for Eskom, with the viability of the organisation declining progressively as costs increased and revenues declined amid frequent leadership changes.

Between 2007 and 2010, the capacity expansion budget increased from R150bn to R368bn (Eskom, 2007, 2010). The first unit at Medupi was optimistically due in 2012, but eventually completed by 2015 . Delays related to civil works, labour disputes and material fraudulent defects on the boiler construction. ${ }^{8}$ By 2019, 6 of the 12 coalfired units had been commissioned; 5 commercialised and in service at Medupi and 1 commercialised at Kusile with other units commissioned but three still under construction. Ingula Power station was commissioned in 2015, two years later than initially planned, with an original cost estimation of around R8bn, surging to R25bn. Delays at this project were due to civil works and an extended labour stoppage after a major accident in which 6 people lost their lives.

With capital becoming increasingly scarce in this period and diverted to the new build programme, the sustained under-investment in the Transmission and Distribution wires businesses and in the cost-plus coal mines became critical. The capital shortage was exacerbated by increasing new build project costs and the continuous commissioning extensions.

From 2015, Eskom made a concerted effort to transform the ownership of the existing 40 -year coal supply agreements from the diversified global mining companies to new Broad-Based Black Economic Empowerment entrants. Unfortunately, there was not a robust strategy to ensure security of coal supply in line with this transformation objective. Eskom indicated publicly that they no longer wanted to be contractually vested in the coal mining operations and would prefer to purchase coal from a diversified and competitive supplier $\mathrm{mix}^{9}$ on the short-term market. This purchasing strategy,

8 In 2015, the Securities and Exchange Commission (SEC) charged Hitachi, Ltd with violating the Foreign Corrupt Practices Act (FCPA) when it inaccurately recorded improper payments to South Africa's ruling political party, the ANC, in connection with the multi-billion-dollar boiler contracts at the Medupi and Kusile power plants. Hitachi agreed to pay $\$ 19 \mathrm{~m}$ to settle the SEC charges (U.S. SEC, 2015).

9 In the Eskom 2016 Integrated Report they note that they embarked on "Changes to the Primary Energy business strategy, in order to create a competitive coal market, by creating equal opportunities for emerging mining companies, and collaborating with Transnet to expand the rail network to all coal-fired power stations" (Eskom, 2016, p. 53). 
in addition to the sustained under-investment in the tied-collieries, contributed to another decline of the coal stockpiles, leading to a second coal emergency in a decade being declared in November 2018. This purchasing strategy led to a steep increase in coal costs as high volumes had to be trucked over longer distances. By 2019, the Board revoked this decision and reverted their coal strategy to re-establishing the tightly coordinated coal supply and logistics chain between dedicated coal mines and power stations (Eskom, 2019a).

In terms of revenue, in the period from 2008-2012, customer arrear debt levels averaged $0.89 \%$ of revenue $(\sim \mathrm{R} 665 \mathrm{~m})$, with Soweto residents' debt ${ }^{10}$ comprising the largest portion of this (Eskom, 2013; Khumalo, 2019). From 2013-2018, average arrear debt levels increased to $2.7 \%$ of revenue $(\sim \mathrm{R} 3500 \mathrm{~m})$ and ranged from $1.1 \%$ of revenue in $2013(\sim \mathrm{R} 1500 \mathrm{~m})$ to an unsustainable $4.21 \%$ of revenue in $2018(\sim \mathrm{R} 7500 \mathrm{~m})$ (Eskom, 2019a). ${ }^{11}$ The main contributor, to this phenomenal rise in customer arrears was a decline in municipal payment levels, over and above the continued low payment levels in Soweto. At year end March 2019, total municipal arrear debt amounted to R19.9bn, with 20 municipalities accounting for $81 \%$ of that arrear debt. ${ }^{12}$ The contributing factors to this revenue loss was an inability to exercise legal credit control processes and the limited results of government-led processes to address municipal government payment performance.

10 There is a long-standing history to the accumulated debt in Soweto. Initially organised as an anti-apartheid protest, continued non-payment of electricity post 1994, was in protest to the commodification of the resources necessary for survival and life (Naidoo \& Veriava, 2009).

11 An exasperated Eskom complain in their 2019 Integrated Report "that total invoiced municipal arrear debt (including interest) continues to deteriorate, increasing from R13.6bn at 31 March 2018 to R19.9bn at year end, with the top 20 defaulting municipalities contributing almost $81 \%$ of total invoiced municipal arrear debt. We have exhausted many of the avenues within our control to recover the money, such as interrupting supply to defaulting municipalities or attaching their assets and installing prepaid meters in pilot project areas. The situation is simply not sustainable, and urgent Government intervention is being sought to resolve the current impasse" (Eskom, 2019a, p. 79).

12 Arrear debt refers only to overdue amounts, excluding interest, and not the total amount due. In August 2019, National Treasury noted, in their report, The State of Local Government Finances and Financial Management as at 30 June 2018, that while most of the 257 municipalities are in reasonably good shape, about 125 municipalities are in varying degrees of financial distress. The number of municipalities adopting funded budgets from 2013/14 to 2018/19 declined by $20.7 \%$ from 169 to 134 . The largest municipal creditors are Eskom and the regional Waterboards. National Treasury also noted that the non-payment risks building up in local government are not systemic in nature but require concerted intervention from government to mitigate. 
A feature of this decade was that the source of governance instability shifted internally. As revealed at the Zondo Commission, from 2014, the ethical tone of successive CEOs and the broader leadership declined ${ }^{13,14,15}$ with direct instructions to over-ride governance controls and intervene in the procurement and supply chains of Eskom (Corruption Watch, 2019e, 2020). Under the Executive leadership of Brian Molefe and Anoj Singh (Corruption Watch, 2019a, 2019c), Eskom's role and actions in the transfer of ownership of Optimum Coal Mine from Glencore to Tegeta ${ }^{16}$ is a case in point (Chipkin \& Swilling, 2018).

Concurrently, employee relations deteriorated dramatically in this period, affecting operations and energy security in the country. ${ }^{17}$ The role of the Board to ensure that the company was a going concern, ensure long-term energy security and to protect it from shareholder and other stakeholder interference, was weak in this period. The corrosive effect of leadership malfeasance left the company scarred with deep levels of distrust. A complete loss of business agility and an inability to control costs and respond to operational crises became entrenched, leading to the second major coal stockpile depletion in November 2018 and deep load-shedding in March 2019.

13 In 2015, external legal opinion found the contract that Colin Matjila irregularly signed with The New Age for R43m in 2014 constituted a financial misconduct (Corruption Watch, 2020).

14 Eskom Head of Treasury Andre Pillay revealed under oath at the Zondo Commission, that a R25bn loan facility signed in 2017 by then interim CEO Sean Maritz was a grossly flawed process that exposed interference from then Board Chairperson, Zethembe Khoza, and former public enterprises minister, Lynn Brown. Maritz resigned in early 2018, just before the current Board could institute disciplinary action against him for his participation in the transaction (Corruption Watch, 2019e).

15 Gert Opperman, a coal supply Manager at Eskom, under oath at the Zondo Commission, revealed that he directly received calls from Matshela Koko, former acting CEO, twice, who, as head of generation in 2015 instructed him to accept substandard coal at Majuba Power Station (Corruption Watch, 2019b; Cronje, 2019a). Substandard coal contributes to higher levels of generator unavailability.

16 Evidence presented under oath to the Zondo Commission has described how Eskom's senior leadership Brian Molefe, Anoj Singh, Matshela Koko and Ayanda Nteta, leveraged their positions to allegedly assist Gupta linked Tegeta Exploration and Resources accusation of Optimum Coal Mine. This entailed implementing contract penalties, resisting business rescue solutions for Optimum (Corruption Watch, 2019d; Seleka, 2019) and in 2016, fast-tracking extraordinary Board resolutions and irregularly providing an advance payment of R659m to Tegeta (Corruption Watch, 2019a; Cronje, 2019b).

17 In the Eskom 2019 Integrated Report, the outgoing Chief Executive, Phakamani Hadebe, notes "that without the commitment of those employees who worked together to limit the impact (of severe industrial action and breakdown in relations), the results could have been much worse. We are truly grateful for their efforts." 


\subsection{WHAT ARE THE KEY ISSUES AT PLAY?}

Having listed critical events where the rules changed in the institutional framework of Eskom, one could attempt to reflect on the dynamics that produced this fundamental weakening of the institution. Jaglin and Dubresson (2016, p. 6, citing Hecht) note that Eskom is fundamentally viewed as a technopolitical object through which technology and politics are entangled for "the strategic practice of designing or using technology to constitute, embody or enact political goals". With this view prevailing, Eskom as a corporatised SOE, is unable to influence its business environment effectively and remains constrained by the following dynamics:

- The contradictions of state policy manifests in the entity with the ultimate price a weakening of the balance sheet;

- The inability to execute any decisions in its own interest as the interests of its stakeholders and shareholders dominate; and

- The demonstration of "lock-in" by all stakeholders and their ability to enact violence on the SOE is a constant imminent threat.

The impact of these three dynamics is particularly important in the economic regulatory regime, the multiple and conflicting decisions of the shareholder, the inability to execute on credit control, the limited flexibility on coal resource management, the internalisation of all risks of the new build programme and engagement on staff remuneration, benefits and job security. In the next section, these dynamics are linked to specific key events which weakened the organisation.

\subsubsection{Contradictions of State Policy Manifesting in the Entity and Weakening the Balance Sheet}

\subsubsection{The Shareholder and its Multiple Roles}

There is inherent tension arising out of having three ministries playing a role as energy and environmental policy-maker/regulator, equity shareholder, and company shareholder representative, first by virtue of the number of integration points, exacerbated by limited alignment within the administration on the direction of the sector in terms of energy security, cost reflectivity, environmental footprint, electricity industry structure and transformational objectives for economic inclusion and transition.

\section{- Shareholder Representative}

Continuing with the liberalisation of the institutional framework for SOEs in 2001, the Eskom Conversion Act, (No. of 13 2001) replaced the 1987 Act and converted Eskom into a competitive organisation operating in a competitive market (Jaglin \& 
Dubresson, 2016, p. 26) and subject to the Companies Act (No. 61 of 1973). While the utility remained state owned, the relationship dynamic between the utility and the government shifted critically, with the latter now playing the roles of energy policy maker, economic regulator, environmental regulator, shareholder and appointer of the Board and Executive leadership, with the utility becoming subordinate in the relationship yet accountable for the management of the contradictory requirements from these different spheres of government.

Khoza and Adam (2005, p. 219) noted "within this commercial context, there are mechanisms which can be utilised to accommodate the peculiar needs of the government as a shareholder. One such mechanism is the shareholder performance agreement". While it appears to be a credible legal arrangement, there is no protection for the SOE if a shareholder request is not feasible when balanced against the main mandate of the entity and its cost structure. An example of abuse of the shareholder compact process - to the detriment of Eskom and the country - was the request by the Department of Public Enterprises (DPE) to change the procurement requirements to companies with black ownership of $50 \%$ plus $1 \%$. This fundamentally reduced the security of coal supply and increased costs tremendously.

Another example of the entity adhering to contradictory shareholder requirements was the "keeping on the lights" edict by utilising diesel generation without any certainty of recovering the costs from the regulator or the shareholder, to the serious detriment of the balance sheet, while potentially compromising the Board and Executive Management legally. Eskom, being the de facto and not de jure supplier of last resort created a decision-making bind that was financially constricting which persists till today (Eskom, 2019a). Invariably the trade-offs were made to the detriment of the financial health of the company.

\section{- Shareholder Equity and Debt Management}

Inherent in the NERSA regulatory framework was an assumption of shareholder equity ratios, generally not met by the National Treasury fiscal support framework. The National Treasury instead opted to support an extended price path to cost reflectivity with a deep government guarantees package that enabled the utility to have enhanced access to the debt capital markets.

Concurrent with the phased approach to cost reflectivity, the lack of an adequate shareholder capital injection, despite the weak balance sheet and deep capital expansion programme, resulted in the new build programme being largely debt-financed. The risk of inadequate utility revenues, either through an inadequate implementation of the economic regulatory model or steep utility cost escalations, was recognised by the National Treasury. However, one of the assumptions underpinning both the Eskom 
and National Treasury view at the time, was that electricity volumes would grow and that an appropriate price trajectory would eventually prevail. These assumptions did not materialise. The credit rating profile of the company deteriorated significantly from 2008 to 2019, with the ratings agencies noting the instability in the economic regulatory framework as a key weakness. This was another example where the balance sheet deteriorated due to the choices of the shareholder.

The decision to support the build programme with government guarantees, instead of a larger equity injection in proportion to the size of the capital investment, created a high-risk condition for the Sovereign, which has subsequently materialised. The Sovereign's declining credit profile, due to the extensive support it provides to Eskom, has created a systemic risk for the local financial system.

\subsubsection{Economic Development Enabler}

Between the National Treasury and the Department of Energy, there was an uneven understanding of the implications of the increasing energy insecurity whilst operating an integrated grid. Being the sole shareholder of the dominant energy supplier, the government also underestimated the systemic risk and pressure it would come under from the public. Being the supplier of last resort, in an energy intensive country dependent on cheap, reliable electricity was frequently discussed, but not effectively acted on until the lights started going out; a point at which long-term economic damage had already been sustained.

In the period 2010 to 2014 , the major deviations from the economic regulatory rules compounded the severe revenue shortfalls by up to R255bn over the regulatory periods. The shareholder reviewed many funding options to reduce risk in 2010, from the sale and lease back of assets, to strategic equity partners and recapitalisation, in line with the agreed economic regulatory capital structure (60:40), but chose to support the electricity sector with the initial provision of R150bn in guarantees, which were later extended to R350bn. This ensured that Eskom gained secured and preferential access to the commercial debt markets.

Initially, with a 25\% per annum increase to the tariff in MYPD2, there was an opportunity for Eskom to achieve tariffs within the cone of cost-reflectivity published by NERSA at the time (Joubert, 2019). However, the shareholder request in 2012, to reduce electricity tariffs from $25 \%$ to $16 \%$ in the last year of the determination scuppered that path and became a tipping point in the decline of Eskom's financial health. The Eskom leadership, while recognising the danger of reducing the tariff increase, acceded to the shareholder request to provide relief to electricity consumers and requested regulatory approval to implement a reduced tariff of $16 \%$. This was 
done on the basis that a new trajectory to cost-reflectivity would be supported in the next regulatory determination. However, the tariff adjustment agreement with the shareholder was not honoured in the light of political pressure from trade unions - in particular the Congress of South African Trade Unions and the National Union of Metalworkers of South Africa. With the threat of limited support for the governing party in the 2014 general election, the integrity of the economic regulatory regime was further diminished and the resultant MYPD3 determination was woefully inadequate, with a price determination of $8 \%$ per annum for three years. This was one of the direct contributors to Eskom's technical and liquidity insolvency and subsequent dependency on the fiscus.

\subsubsection{Regulatory Framework and Energy Pricing Policy}

Inherently, the regulatory regime introduced post the De Villiers commission is a credible one. However, in the context of Eskom and electricity industry viability in South Africa, there have been several serious flaws which need to be addressed. There are three areas in which the regulatory regime fundamentally must be reviewed if long term industry viability is to be achieved and they relate to the challenges highlighted in the Eskom tipping points timelines sketched earlier. These areas are: an appropriate implementation of cost-reflectivity which balances consumer protection with industry sustainability, an effective dispute and appeal mechanism, ${ }^{18}$ and forwardlooking industry investment and expansion.

From the start of the build programme, NERSA attempted to protect electricity consumers from tariff spikes. ${ }^{19}$ That culminated in a decade-long series of enormous revenue shortfalls, increased levels of borrowing, and finally a company liquidity crisis in 2018 and a national fiscal crisis in $2019 .^{20}$

18 In the Eskom Road Map, published by the Department of Public Enterprises, proposed amendments to the NERSA Act strengthening the utilities' ability to have timeous recourse on a regulatory decision, is highlighted (Eskom, 2019b).

19 By minimising the return on assets in the regulatory formulae, NERSA attempted to control the rate at which revenue could increase and hence the annual tariff adjustments that could be implemented. By NERSA granting Eskom a return on assets, significantly lower than their weighted average cost of capital (WACC), the balance sheet weakened over time. The return on asset is also needed to support the debt service requirements for new investments and ensure sufficient surplus operational cash flows to meet short-term liquidity requirements and longterm debt commitments.

20 Eskom notes in the Eskom 2019 Integrated Report that, NERSA's revenue decision for 2018/19, which granted a $5.23 \%$ standard tariff price increase for the year, indicates that NERSA did not consider Eskom's sustainability when it made its decision, in contravention of its mandate. Other examples of contested regulatory decisions include the precedent not to compensate Eskom for extraordinary diesel usage during periods of generation constraints to minimise 
Maintaining a low electricity price (via a price compact or incentive-based regulation) for 20 years (1987-2006) produced a distinct South African electricity cost competitive advantage. However, the inevitable price adjustment to new industry investments was too steep to bear, with inordinate pressure on Eskom and the NERSA during the MYPD processes, especially as the economic strain was severe and had been exacerbated by the global financial crisis. To date, the price path adjustment to costreflectivity has still not been achieved with more volatility in applying the regulatory rules consistently ${ }^{21}$ and timeously, leading to the liquidity crises at Eskom and a deep exposure for the national fiscus (Joubert, 2015; Eskom, 2019).

\subsubsection{An Inability to Execute Decisions in its Own Interest}

\subsubsection{Arrear Debt Management}

Another area of conflict between the shareholder representative and Eskom was when the latter tried to exercise credit management with non-paying municipalities. Having followed lengthy public and government-led processes, Eskom was either prevented from interrupting electricity supply to municipalities by political principals or was prevented legally by a customer successfully interdicting Eskom from interrupting the supply despite their municipality, as the direct electricity supplier, being the party in default. This was an instance where Eskom could not exercise decisions in its own interest, suffering dire financial consequences as a result.

\subsubsection{Coal Contracts and Logistics Management}

The most extreme example of Eskom being unable to execute on a decision in the interests of the public good, public safety and sound generation power station production and financial health, is in the coal supply to Kusile power station. The siting of Kusile next to the New Largo coal mine, was based specifically on the ability to use a conveyor belt to transport the coal from the mine into the power station. To date, 12 years after the construction of the power station commenced, the coal mine contract has not been concluded. Largely this has been due to a shareholder request to have enhanced the BEE credentials for the coal mine.

the economic impact of load-shedding. The erosion of the financial sustainability of the company, finally lead to full dependency on the fiscus for liquidity support and the transfer of extraordinary financial support to Eskom to avoid a call on its existing guarantees (National Treasury, 2019).

21 Eskom took the NERSA 2018/2019 Regulatory Determination to the High Court for review. In March 2020, Judge N. Kollapen concurred with Eskom that the NERSA's decisions were procedurally unfair, irrational and unreasonable and falls to be reviewed (High Court of South Africa: North Gauteng, 2020). 


\subsubsection{The Demonstration of Lock-in by Stakeholders and the Willingness to Resort to Violence}

\subsubsection{The Integration of the New Build Programme}

Eskom integrated the main civil, boiler, turbine, protection, cabling and auxiliary plant component contracts for the coal-fired power stations in the build programme. Having to ensure coordination between all the major contract components presented a massive informational task, leading to integration mismatches and sub-optimal situational awareness. In addition, the equipment suppliers were aware of the utility's vulnerability and the country's energy hunger and hence capitalised on the chaotic trade-offs that had to be made in meeting tight commissioning timelines or in keeping the lights on in the short-term versus properly repairing a defective unit. While not corrupt, this kind of rent-seeking was opportunistic, demonstrating a supplier "lockin" and was a further drain on Eskom's finances.

In hindsight, bundling the role of the project developer and integrator within the same Eskom holding company as the main operational and maintenance business, was a critical strategic error. It meant that vital resources were diverted from the existing operations to the build programme, a practice that has continued even after the build programme went awry. This decision was taken at a time when the company had limited skills capability to maintain its operations and maintenance activity. It launched into the complex mega-build programme with a very lean project office. In terms of design, the Eskom project teams had all the suppliers' designs verified independently. However, the integration and optimisation of the critical engineering value chain, for example, the extended boiler operations, was not optimised with one overarching approach, leading to operational challenges that are only now apparent, after more than half the power station units at both Medupi and Kusile have become operational.

\subsubsection{Annual Salary Negotiations}

As a result of a bargaining unit wage dispute between Eskom and organised labour in June 2018, national industrial action was instituted by the bargaining unit, which led to rotational load-shedding over three days. Eskom reports that this was the largest and most complex incident ever managed by their integrated incident command structures (Eskom, 2019). Revealing the nature of this incident, Eskom obtained court interdicts to prevent the tripping of generation power supplies, the hijacking of coal trucks, the interference with coal supply logistics, the blocking of building entrances and the intimidation of employees and contractors from doing their work (Gous, 2018). As one of the most critical stakeholders in Eskom, the staff are conflicted because they are well-paid, work incredibly hard and do not feel accountable for 
the poor governance decisions taken at a leadership level. However, by disrupting electricity production processes to reflect their anger, they have broken the social compact and raised the risk of the likelihood of a blackout due to labour unrest. The final 3-year wage agreement includes a minimum 7\% per annum salary increase, inflationary house allowance adjustments and a once-off cash after tax payment of R10 000, for all bargaining forum employees. ${ }^{22}$

\subsection{WHAT DO WE DO NOW?}

If viewed through the lens of a complex adaptive system, it appears that Eskom has lost its ability to self-organise for business viability.

This manifests in an inability to execute decisions in its own interest or to manage the prevailing socio-political dynamics to create a conducive business environment, specifically in securing adequate regulatory rulings or appropriate shareholder support when needed.

Lastly, Eskom appears unable to execute any adaptation necessary for it to remain fit for purpose, despite being aware of the extreme nature of the risks it faces.

It is critical that these constraints in its business environment, specifically arising from the multiple roles of the shareholder, are understood and mitigated. Next, it is important to re-establish the rules supporting the industry to ensure that any incumbent survives, has the capacity to access capital markets, and can credibly undertake long-term decisions in the public interest. If not, any attempt to restructure the industry may provide transparency in terms of costs and visibility of services but will not succeed in establishing a new or sustainable industry.

22 Eskom reports that, subsequent to this violent industrial action incident, learnings have been documented and that their Industrial Action Working Group have addressed the gaps identified in securing production processes. Following the conclusion of the three-year wage agreement, the trade unions, as well as non-unionised senior Management, lodged a dispute with the Council for Conciliation, Mediation and Arbitration (CCMA) regarding Eskom's decision to award no increase to senior Management, despite the wage agreement with bargaining unit employees and the inflationary salary increase of $4.7 \%$ provided to middle Management/ professionally qualified employees. 


\section{References}

Chipkin, I. \& Swilling, M. (eds.) (2018) Shadow State: The Politics of State Capture. Johannesburg: Wits University Press. https://doi.org/10.18772/22018062125

Conradie, S.R. \& Messerschmidt, L.J.M. (2000) A Symphony of Power: the Eskom story. Johannesburg: Chris van Rensburg Publications.

Corruption Watch (2019a) Zondo Commission - Multi-million-rand Tegeta payment rushed through under irregular circumstances [5 March 2019]. [Online]. https://bit.ly/ 3 ir6tUa (Accessed 23 July 2020).

Corruption Watch (2019b) Zondo Commission - Power station forced to accept sub-standard coal from Gupta company [11 March 2019]. [Online].https://bit.ly/3g07rVZ (Accessed 23 July 2020).

Corruption Watch (2019c) Zondo Commission - Dodgy machinations behind Eskom's insistence of Optimum sale to Oakbay. [Online].https://bit.ly/3ixhqDu (Accessed 23 July 2020).

Corruption Watch (2019d) Zondo Commission - Eskom execs, including Molefe, refused to listen to reason in Optimum case [12 March 2019]. [Online]. https://bit.ly/3ClvpV7 (Accessed 23 July 2020).

Corruption Watch (2019e) Zondo Commission - Eskom pressed to sign up for dodgy R25bn loan agreement [1 March 2019]. [Online]. https://bit.ly/3s1K0QT (Accessed 23 July 2020).

Corruption Watch (2020) Zondo Commission - Eskom's Gupta contract under scrutiny [23January 2020]. [Online]. https://bitly/ 3jrhW5e (Accessed 24 July 2020).

Cronje, J. (2019a) 'Eskom's Koko insisted we accept sub-standard coal, Zondo hears', Fin24. [Online]. https://bit.ly/3s2j03B (Accessed 24 July 2020).

Cronje, J. (2019b) 'Inquiry hears Eskom tender committee resolved to pay Tegeta R659m before contract was signed, Fin24. [Online]. https://bit.ly/3ArrTal (Accessed 24 July 2020).
Department of Minerals and Energy (2008) South African Electricity Supply Industry: Electricity Pricing Policy (EPP). [Online]. https://bit.ly/3s0qBj6 (Accessed 24 July 2020).

Eberhard, A. (2007) 'The Political Economy of Power Sector Reform in South Africa,' in D.G. Victor \& T.C. Heller (eds.) The Political Economy of Power Sector Reform: The Experiences of 5 Major Developing Nations. Cambridge: Cambridge University Press.

Eskom (2003) Eskom Annual Report 2003. Johannesburg. [Online]. https://bit.ly/ 3jvxV2w (Accessed 18 December 2019).

Eskom (2007) Eskom Annual Report 2007. Johannesburg. [Online]. https://bit.ly/ 3f JspZ0

Eskom (2010) Eskom Integrated Report 2010. Johannesburg. [Online]. https://bit.ly/ 3fF4BFm

Eskom (2013) Eskom Integrated Report 2013. Johannesburg. [Online]. https://bit.ly/ 3jvyidq

Eskom (2016) Eskom Integrated Report 2016. Johannesburg. [Online]. https://bit.ly/ 3CuyKku (Accessed 18 December 2019).

Eskom (2019a) Eskom Integrated Report 2019. [Online]. https://bit.ly/3CuJWO4

Eskom (2019b) Roadmap for Eskom: In A Reformed Electricity Supply Industry. [Online].https://bit.ly/3fJOhDp

Fine, B. \& Rustomjee, Z. (1996) The Political Economy of South Africa: From Minerals Energy Complex to Industrialisation. Johannesburg: Witwatersrand University Press.

Gentle, L. (2009) 'Escom to Eskom: From racial Keynesian capitalism to neo-liberalism (1910-1994)', in D.A. McDonald (ed.) Electric Captalism: Recolonising Africa on the Power Grid. Cape Town: HSRC Press, pp. 50-72. [Online]. https://bit.ly/3Art4WZ (Accessed 24 July 2020).

Gous, N. (2018) 'National shutdown looms if Eskom wage negotiations remain deadlocked', Times Live. [Online]. https://bitly/3iuZNEH (Accessed 17 December 2019). 
High Court of South Africa: North Gauteng (2020) Eskom Holdings SOC Limited $\checkmark$ National Energy Regulator of South Africa and Others (74870/2019) [2020] ZAGPPHC 2, 10 February. [Online]. https:// bit.ly/3yydmZl (Accessed 24 July 2020).

Jaglin, S. \& Dubresson, A. (2016) ESKOM: electricity and technopolitics in South Africa. South Africa: Juta and Company (Pty) Ltd.

Joubert, D. (2015) 'Funding of Investment for Asset Replacement and Expansion of Regulated Infrastructure Industries: theoretical criteria and parameters to ensure adequate capital', in 1st Annual Competition and Economic Regulation (Acer) Week, Southern Africa 20 \& 21 March 2015. Victoria Falls: Centre for Competition, Regulation and Economic Development (CCRED). [Online]. https://bitly/ 2VCRVYR (Accessed 18 December 2019).

Joubert, D. (2019) 'Eskom Corporate Specialist'. Interview, 12 September.

Khoza, R. \& Adam, M. (2005) The Power of Governance: Enhancing the Performance of State-Owned Enterprises. 1st Ed. Johannesburg: Pan MacMillan and Business in Africa.

Khumalo, N. (2019) 'Analysis: Does Soweto owe Eskom R18 billion in unpaid electricity?', Africa Check. [Online]. https://bit.ly/ 3iqQHIR (Accessed 23 July 2020).

Mbeki, T. (2008) 'State of the Nation Address of the President of South Africa, Thabo Mbeki: Joint Sitting of Parliament', South African Government. [Online]. https://bit.ly/ 3xwiLyL (Accessed 24 July 2020).

Naidoo, P. \& Veriava, A. (2009) 'From local to global (and back again?): Anticommodification struggles of the
Soweto Electricity Crisis Committee', in D.A. McDonald (ed.) Electric Captalism: Recolonising Africa on the Power Grid. Cape Town: HSRC Press.

National Treasury (2009) National Budget Review [2009]: Chapter 5-Asset and liability management. Pretoria.

National Treasury (2019) Budget Review 2019. Pretoria: Government Printers.

NERSA (National Energy Regulator of South Africa) (2006) Multi-Year Price Determination of Eskom: 1 April 2006 to 31 March 2009, Final Determination - with condition. Pretoria.

NERSA (National Energy Regulator of South Africa) (2008) 'Inquiry Into the National Electricity Supply Shortage and Load Shedding: Report by the Energy Regulator', Parliamentary Monitoring Group (PMG). [Online]. https://bit.ly/3Ck8kSy (Accessed 24 July 2020).

PMG (Parliamentary Monitoring Group) (2012) Energy Portfolio Committee: Update on the Eskom-led New Build Programme. [Online]. https://bit.ly/37smaUI (Accessed 24 July 2020).

Seleka, N. (2019) 'Eskom left Optimum out in the cold, says former business rescue practitioner', Fin24. [Online]. https://bit.ly/3s8wQBC (Accessed 24 July 2020).

Stats SA (2019) Gross Domestic Product (GDP), 2nd Quarter 2019 Media presentation. [Online].https://bit.ly/2TZdAK0 (Accessed 18 December 2019).

U.S. Securities and Exchange Commission (SEC) (2015) Press Release: SEC Charges Hitachi With FCPA Violations. [Online]. https:// bit.ly/3ithzYD (Accessed 24 July 2020). 


\section{APPENDIX}

\begin{tabular}{|c|c|c|c|c|}
\hline $\begin{array}{l}\text { Case Study } \\
\text { in State } \\
\text { Capture }\end{array}$ & Status & Summary Description & $\begin{array}{l}\text { Investigation } \\
\text { Body / } \\
\text { Source of } \\
\text { Evidence }\end{array}$ & $\begin{array}{l}\text { Government } \\
\text { Entity } \\
\text { Implicated }\end{array}$ \\
\hline \multicolumn{5}{|c|}{ Scandals Connected to Jacob Zuma, Guptas, Other Key Networks and ANC Politics } \\
\hline $\begin{array}{l}\text { The State } \\
\text { of Capture } \\
\text { report- } \\
\text { focuses } \\
\text { on Guptas' } \\
\text { relationship } \\
\text { with Jacob } \\
\text { Zuma and } \\
\text { their alleged } \\
\text { influence on } \\
\text { the affairs } \\
\text { of state }\end{array}$ & $\begin{array}{l}\text { First complaint } \\
\text { was received } \\
\text { in March } 2016 \\
\text { and the report } \\
\text { was released in } \\
\text { November } 2016 .\end{array}$ & $\begin{array}{l}\text { Investigation into complaints of alleged improper } \\
\text { and unethical conduct by the President and } \\
\text { other State Functionaries, relating to alleged } \\
\text { improper relationships and involvement of the } \\
\text { Gupta Family in the removal and appointment } \\
\text { of Ministers and Directors of State-Owned } \\
\text { Enterprises (SOEs), resulting in improper and } \\
\text { possibly corrupt award of State Contracts and } \\
\text { Benefits to the Gupta Family's Businesses. } \\
\text { The report details numerous allegations of } \\
\text { the Guptas' involvement in affairs of the state } \\
\text { and their irregular activities that enable rent } \\
\text { extraction. The findings were not conclusive } \\
\text { and the remedial action was to establish a } \\
\text { commission of inquiry into state capture (to } \\
\text { be appointed by the President, but with a } \\
\text { judge selected by the Chief Justice). Litigation } \\
\text { endeavoured to delay or prohibit the report's } \\
\text { release and implementation of remedial actions, } \\
\text { but failed, and the commission was established } \\
\text { in } 2018 \text {. }\end{array}$ & $\begin{array}{l}\text { - Public } \\
\text { Protector, } \\
\text { followed by } \\
\text { litigation }\end{array}$ & $\begin{array}{l}\text { - GCIS (The } \\
\text { New Age) } \\
\text { - Eskom } \\
\text { (Optimum) } \\
\text { - Transnet } \\
\text { (Regiments/ } \\
\text { Trillian) } \\
\text { - Denel } \\
\text { - SAA (The } \\
\text { New Age) } \\
\text { - SABC (The } \\
\text { New Age) } \\
\text { - Department of } \\
\text { Finance } \\
\text { - Transport } \\
\text { (SAA) } \\
\text { - Communica- } \\
\text { tions (SABC } \\
\text { \& GCIS) }\end{array}$ \\
\hline $\begin{array}{l}\text { Zondo } \\
\text { Commission }\end{array}$ & $\begin{array}{l}\text { Established } \\
\text { in 2018, with } \\
\text { anticipated } \\
\text { conclusion being } \\
\text { the end of } 2021 .\end{array}$ & $\begin{array}{l}\text { Formally titled the Judicial Commission of } \\
\text { Inquiry into Allegations of State Capture, } \\
\text { Corruption and Fraud in the Public Sector } \\
\text { including Organs of State, the Commission } \\
\text { was promulgated by then President Zuma in } \\
\text { response to the remedial actions as outlined in } \\
\text { the Public Protector's State of Capture report. } \\
\text { As of June } 2021 \text {, the Commission that started } \\
\text { in August } 2018 \text { has held more than } 418 \text { days } \\
\text { of hearings of over } 330 \text { testimonies (generating } \\
\text { over } 71000 \text { pages of transcript). The inquiry's } \\
\text { terms of reference were expansive and, as } \\
\text { such, the scope of investigations went beyond } \\
\text { merely looking into the Gupta-related cases, } \\
\text { covering other networks (e.g., Bosasa) as well } \\
\text { as other government institutions (e.g., role } \\
\text { of Parliament). }\end{array}$ & $\begin{array}{l}\text { - Zondo } \\
\text { Commission }\end{array}$ & $\begin{array}{l}\text { Various } \\
\text { work-streams } \\
\text { covering } \\
\text { inter alia: } \\
\text { - SOEs } \\
\text { (Eskom, } \\
\text { Transnet, } \\
\text { Denel, SAA) } \\
\text { - Free State } \\
\quad \text { Provincial } \\
\text { Government } \\
\text { - Bosasa } \\
\text { - SARS } \\
\text { - Law } \\
\text { enforcement } \\
\text { - State Security } \\
\text { Agency (SSA) } \\
\text { - The New Age } \\
\text { \& ANN7 } \\
\text { - Role of } \\
\text { Parliament } \\
\text { and ANC }\end{array}$ \\
\hline
\end{tabular}




\begin{tabular}{|c|c|c|c|c|}
\hline $\begin{array}{l}\text { Case Study } \\
\text { in State } \\
\text { Capture }\end{array}$ & Status & Summary Description & $\begin{array}{l}\text { Investigation } \\
\text { Body / } \\
\text { Source of } \\
\text { Evidence }\end{array}$ & $\begin{array}{l}\text { Government } \\
\text { Entity } \\
\text { Implicated }\end{array}$ \\
\hline \multicolumn{5}{|c|}{ Scandals Connected to Jacob Zuma, Guptas, Other Key Networks and ANC Politics } \\
\hline Bosasa & $\begin{array}{l}\text { Dating back to a } \\
2009 \text { SIU report. } \\
\text { Investigations and } \\
\text { various litigations } \\
\text { are ongoing. }\end{array}$ & $\begin{array}{l}\text { In 2019, former Bosasa C00, Anglo Agrizzi, } \\
\text { testified at the Zondo Commission, detailing } \\
\text { the acts and long history of corruption between } \\
\text { various Bosasa companies predominantly } \\
\text { owned by Gavin Watson, and numerous } \\
\text { government entities/departments. The } \\
\text { testimony of Agrizzi (and other former Bosasa } \\
\text { employees) corroborated the findings of a } \\
2009 \text { SIU investigation that alleged corruption } \\
\text { in several contracts Bosasa had with the } \\
\text { Department of Correctional Services. Criminal } \\
\text { court proceedings have been initiated based } \\
\text { on the } 2009 \text { SIU investigation, along with new } \\
\text { investigations initiated by SARS and other law } \\
\text { enforcement entities. }\end{array}$ & $\begin{array}{l}\text { - Special } \\
\text { Investi- } \\
\text { gation } \\
\text { Unit (SIU) } \\
\text { - Zondo } \\
\text { Commission }\end{array}$ & $\begin{array}{l}\text { - Department of } \\
\text { Correctional } \\
\text { Services } \\
\text { - Department of } \\
\text { Justice } \\
\text { - Department of } \\
\text { Home Affairs } \\
\text { - Department of } \\
\text { Transport } \\
\text { - Various SOEs } \\
\text { (e.g., SAPO, } \\
\text { ACSA) } \\
\text { - National } \\
\text { Prosecuting } \\
\text { Authority } \\
\text { (NPA) } \\
\text { - Members of } \\
\text { Parliament }\end{array}$ \\
\hline Arms Deal & $\begin{array}{l}\text { Various } \\
\text { investigations and } \\
\text { sources, dating } \\
\text { back to 1990s. } \\
\text { Most significant } \\
\text { source being } \\
\text { through Seriti } \\
\text { Commission. } \\
\text { Corruption case } \\
\text { against Zuma is } \\
\text { ongoing. }\end{array}$ & $\begin{array}{l}\text { Commission of Inquiry into allegations of fraud, } \\
\text { corruption, impropriety, or irregularity in the } \\
\text { Strategic Defence Procurement Packages } \\
\text { (SDPP). Various court cases related to } \\
\text { allegations of corruption against Jacob Zuma. } \\
\text { On Monday, } 24 \text { October 2011, the President } \\
\text { announced the Commission chaired by Judge } \\
\text { Seriti. The findings of the Commission were that } \\
\text { there was "no evidence" of corruption, but this } \\
\text { is seen by many to have been a whitewash. The } \\
\text { report was taken on review and set aside in } \\
\text { August 2019. The corruption case against Zuma } \\
\text { is ongoing before the courts. }\end{array}$ & $\begin{array}{l}\text { - Seriti } \\
\text { Commission } \\
\text { - Various } \\
\text { court cases }\end{array}$ & $\begin{array}{l}\text { Initially: } \\
\text { - South African } \\
\text { National } \\
\text { Defence } \\
\text { Force } \\
\text { - Members of } \\
\text { Parliament } \\
\text { Allegations also } \\
\text { involve: } \\
\text { - NPA } \\
\text { - SSA }\end{array}$ \\
\hline $\begin{array}{l}\text { Nkandla } \\
\text { Security } \\
\text { Upgrades }\end{array}$ & $\begin{array}{l}\text { Investigation } \\
\text { started in } \\
\text { November } 2012 . \\
\text { Report on } \\
\text { investigation } \\
\text { was released in } \\
\text { March } 2014 .\end{array}$ & $\begin{array}{l}\text { Report on security upgrades to President } \\
\text { Zuma's homestead in Nkandla. The investigation } \\
\text { found that the President unduly benefited from } \\
\text { the upgrades and as part of remedial actions } \\
\text { the President was required to pay back a portion } \\
\text { of the costs of the upgrades. Zuma instructed } \\
\text { that SAPS undertake their own investigation, } \\
\text { which sought to rationalise the expenses (fire- } \\
\text { pool report). Parliament accepted this alternative } \\
\text { report, but major court cases followed, } \\
\text { ultimately declaring that the Public Protector's } \\
\text { remedial actions are binding. President and } \\
\text { Parliament failed to uphold the Constitution. } \\
\text { President ordered to "pay back the money". }\end{array}$ & $\begin{array}{l}\text { - Public } \\
\text { Protector's } \\
\text { Secured } \\
\text { in Comfort } \\
\text { report, } \\
\text { followed by } \\
\text { litigation }\end{array}$ & $\begin{array}{l}\text { - Department of } \\
\text { Public Works } \\
\text { - South African } \\
\text { Police Service }\end{array}$ \\
\hline
\end{tabular}




\begin{tabular}{|c|c|c|c|c|}
\hline $\begin{array}{l}\text { Case Study } \\
\text { in State } \\
\text { Capture }\end{array}$ & Status & Summary Description & $\begin{array}{l}\text { Investigation } \\
\text { Body / } \\
\text { Source of } \\
\text { Evidence }\end{array}$ & $\begin{array}{l}\text { Government } \\
\text { Entity } \\
\text { Implicated }\end{array}$ \\
\hline \multicolumn{5}{|c|}{ Scandals Connected to Jacob Zuma, Guptas, Other Key Networks and ANC Politics } \\
\hline $\begin{array}{l}\text { Private } \\
\text { Aircraft } \\
\text { Landing at } \\
\text { Waterkloof } \\
\text { Airforce Base } \\
\text { and Gupta } \\
\text { Sun City } \\
\text { Wedding }\end{array}$ & May 2013. & $\begin{array}{l}\text { In 2013, justice, crime prevention, and } \\
\text { security cluster (JCPS) - a cabinet structure } \\
\text { composed of various ministries - undertook an } \\
\text { investigation into the Landing of a Commercial } \\
\text { aircraft at Air Force Base Waterkloof (report } \\
\text { titled the same). The investigation revealed that } \\
\text { the Guptas initially tried to organise a special } \\
\text { landing at OR Tambo International Airport, but } \\
\text { was turned down. They then approached the } \\
\text { Indian High Commission who re-designated the } \\
\text { wedding entourage as an official delegation to } \\
\text { secure a landing at the Waterkloof base. The } \\
\text { wedding held at Sun City was attended by a } \\
\text { number of high-profile ANC politicians and was } \\
\text { paid for in part by moneys looted from the Vrede } \\
\text { Dairy Farm project. }\end{array}$ & $\begin{array}{l}\text { - Report by } \\
\text { JPCS } \\
\text { - Zondo } \\
\text { Commission } \\
\end{array}$ & \begin{tabular}{|l} 
- Department of \\
International \\
Relations and \\
Cooperation \\
(DIRCO) \\
- Department of \\
Defence \\
- Department of \\
Transport
\end{tabular} \\
\hline $\begin{array}{l}\text { Free State } \\
\text { Provincial } \\
\text { Capture, } \\
\text { includes } \\
\text { Vrede Dairy } \\
\text { Farm and } \\
\text { Asbestos } \\
\text { Contracts }\end{array}$ & Ongoing. & $\begin{array}{l}\text { The Vrede Dairy Farm project was initiated } \\
\text { by the Free State Provincial Government as a } \\
\text { development project, however, in partnering with } \\
\text { a Gupta-linked company Estina, government } \\
\text { funds were looted. In 2018, the Public } \\
\text { Protector released a report on their } 2018 \\
\text { investigation, but it was taken on review and } \\
\text { set aside by the courts. The second part of the } \\
\text { investigation is yet to be finalised. The NPA } \\
\text { laid criminal charges against Gupta associates } \\
\text { and implicated government officials. Court } \\
\text { proceedings are ongoing. } \\
\text { Significant testimony and evidence have been } \\
\text { presented at the Zondo Commission regarding } \\
\text { the Vrede Farm case, as well as the asbestos } \\
\text { inspection project (criminal proceedings are also } \\
\text { underway). Both projects implicate high-profile } \\
\text { politicians and senior officials manipulating } \\
\text { government process. }\end{array}$ & $\begin{array}{l}\text { - Public } \\
\text { Protector } \\
\text { reports } \\
\text { - Zondo } \\
\text { Commission } \\
\text { - Various } \\
\text { court cases } \\
\end{array}$ & $\begin{array}{l}\text { - Free State } \\
\text { Provincial } \\
\text { Government }\end{array}$ \\
\hline $\begin{array}{l}\text { Irregular } \\
\text { removal of } \\
\text { National } \\
\text { Director } \\
\text { of Public } \\
\text { Prosecutions } \\
\text { (NDPP), } \\
\text { Mxolisi } \\
\text { Nxasana }\end{array}$ & $\begin{array}{l}\text { Inquiry instituted } \\
\text { in February } 2015, \\
\text { but was cancelled } \\
\text { in May } 2015 . \\
\text { This triggers the } \\
\text { Constitutional Court } \\
\text { cases that followed. }\end{array}$ & $\begin{array}{l}\text { Inquiry into the fitness of Mxolisi Nxasana to } \\
\text { hold office as NDPP. The Inquiry was cancelled } \\
\text { after Zuma "agreed to let Nxasana resign". He } \\
\text { was paid R17m - the balance of his ten-year } \\
\text { contract. Court cases followed detailing the } \\
\text { abuse of the presidency powers by Zuma. } \\
\text { Ultimately, Nxasana was ordered to repay } \\
\text { R17m and Zuma's appointed replacement, } \\
\text { Shawn Abrahams, was ordered to vacate office. } \\
\text { Constitutional Court found Zuma's actions to } \\
\text { be an abuse of power and in breach of his } \\
\text { constitutional obligations. }\end{array}$ & $\begin{array}{l}\text { - Cassim } \\
\text { Inquiry into } \\
\text { fitness of } \\
\text { Mxolisi } \\
\text { Nxasana to } \\
\text { hold office } \\
\text { of NDPP } \\
\text { initiated } \\
\text { by Zuma, } \\
\text { followed by } \\
\text { litigation }\end{array}$ & $\begin{array}{l}\text { - National } \\
\text { Prosecution } \\
\text { Authority }\end{array}$ \\
\hline $\begin{array}{l}\text { Political } \\
\text { killings in } \\
\text { KZN }\end{array}$ & $\begin{array}{l}\text { Established in } \\
\text { October } 2016 . \text { The } \\
\text { report was released } \\
\text { in May } 2018 .\end{array}$ & $\begin{array}{l}\text { On } 28 \text { October 2016, the Premier of the } \\
\text { Province of KwaZulu-Natal established a } \\
\text { Commission of Enquiry into the Underlying } \\
\text { Causes of the Murder of Politicians in KwaZulu- } \\
\text { Natal (KZN). }\end{array}$ & $\begin{array}{l}\text { - Moerane } \\
\text { Commission } \\
\text { of Enquiry }\end{array}$ & $\begin{array}{l}\text { - KZN Provincial } \\
\text { Government } \\
\text { - KZN Local } \\
\text { Governments }\end{array}$ \\
\hline
\end{tabular}




\begin{tabular}{|c|c|c|c|c|}
\hline $\begin{array}{l}\text { Case Study } \\
\text { in State } \\
\text { Capture }\end{array}$ & Status & Summary Description & $\begin{array}{l}\text { Investigation } \\
\text { Body / } \\
\text { Source of } \\
\text { Evidence }\end{array}$ & $\begin{array}{l}\text { Government } \\
\text { Entity } \\
\text { Implicated }\end{array}$ \\
\hline \multicolumn{5}{|c|}{ Scandals Connected to Jacob Zuma, Guptas, Other Key Networks and ANC Politics } \\
\hline \multicolumn{5}{|c|}{ State Capture of State-Owned Enterprises and Government Departments } \\
\hline $\begin{array}{l}\text { Interference } \\
\text { in operations } \\
\text { at the SABC }\end{array}$ & $\begin{array}{l}\text { The Ad Hoc } \\
\text { Committee was } \\
\text { established in } \\
\text { November } 2016 \\
\text { and final report } \\
\text { was tabled on } \\
24 \text { February } 2017 .\end{array}$ & $\begin{array}{l}\text { Parliamentary Ad Hoc Committee on the } \\
\text { SABC Board Inquiry into mismanagement and } \\
\text { interference in SABC operations. Findings } \\
\text { include evidence of Minister Faith Muthambi's } \\
\text { interference in the organisation and editorial } \\
\text { interference, in the firing of SABC } 8 \text { who } \\
\text { protested censorship of the national broadcaster } \\
\text { (on instruction from COO Hlaudi Motsoeneng). It } \\
\text { should be noted that the inquiry was preceded } \\
\text { by an investigation by the Public Protector. } \\
\text { Details are contained in the } 2014 \text { report titled } \\
\text { When Governance and Ethics Fail. }\end{array}$ & $\begin{array}{l}\text { - Parliamen- } \\
\text { tary Inquiry } \\
\text { - Preceded by } \\
\text { an investi- } \\
\text { gation by } \\
\text { the Public } \\
\text { Protector }\end{array}$ & $\begin{array}{l}\text { - SABC } \\
\text { (Department } \\
\text { of Communi- } \\
\text { cation) }\end{array}$ \\
\hline \multirow[t]{2}{*}{$\begin{array}{l}\text { Passenger } \\
\text { Rail Agency } \\
\text { of South } \\
\text { Africa } \\
\text { (PRASA) }\end{array}$} & $\begin{array}{l}\text { Complaints were } \\
\text { lodged in } 2012 \\
\text { and the report } \\
\text { was released in } \\
\text { August } 2015 \text {. }\end{array}$ & $\begin{array}{l}\text { Several cases of "mismanagement and } \\
\text { irregularities" regarding various contracts. } \\
\text { Lucky Montana was CEO at the time. One of } \\
\text { the remedial actions stipulated that National } \\
\text { Treasury was to investigate all PRASA contracts } \\
\text { from } 2012 \text { onwards with a value of R10 million } \\
\text { or more. National Treasury implemented the } \\
\text { remedial action which resulted in several } \\
\text { investigations, the details of which were leaked } \\
\text { to the public. }\end{array}$ & $\begin{array}{l}\text { - Public } \\
\text { Protector's } \\
\text { Derailed } \\
\text { report on } \\
\text { PRASA } \\
\text { - Numerous } \\
\text { investiga- } \\
\text { tions }\end{array}$ & $\begin{array}{l}\text { - PRASA } \\
\text { - Department of } \\
\text { Transport }\end{array}$ \\
\hline & $\begin{array}{l}\text { In June } 2017, \\
\text { Parliament directed } \\
4 \text { committees to } \\
\text { investigate state } \\
\text { capture. Committee } \\
\text { hearings were not } \\
\text { completed. }\end{array}$ & $\begin{array}{l}\text { In terms of the parliamentary directive, the } \\
\text { Portfolio Committee on Transport was requested } \\
\text { to establish an Inquiry into State Capture at } \\
\text { PRASA. However, the Portfolio Committee noted } \\
\text { that PRASA was not mentioned in the Public } \\
\text { Protector's State of Capture report and decided } \\
\text { they would focus on the various investigation } \\
\text { reports produced for National Treasury (as } \\
\text { recommended in Derailed report). }\end{array}$ & $\begin{array}{l}\text { - Portfolio } \\
\text { Committee } \\
\text { on Transport }\end{array}$ & $\begin{array}{l}\text { - PRASA } \\
\text { - Department of } \\
\text { Transport }\end{array}$ \\
\hline $\begin{array}{l}\text { Eskom } \\
\text { Inquiry into } \\
\text { State Capture }\end{array}$ & $\begin{array}{l}\text { In June } 2017 \text {, } \\
\text { Parliament directed } \\
4 \text { committees } \\
\text { to investigate } \\
\text { state capture. } \\
\text { Public Enterprises } \\
\text { Committee } \\
\text { report on Eskom } \\
\text { was released in } \\
\text { November } 2018 .\end{array}$ & $\begin{array}{l}\text { Extensive hearings were held by the Committee } \\
\text { detailing much of the evidence presented in } \\
\text { the Public Protector's report. The Committee } \\
\text { presented recommendations and compiled } \\
\text { a final report detailing their findings. These } \\
\text { included findings that Ministers Lynne Brown } \\
\text { and Malusi Gigaba were negligent and had to } \\
\text { be held accountable. Also recommended that } \\
\text { criminal investigations be undertaken against } \\
\text { the relevant Eskom executives. }\end{array}$ & $\begin{array}{l}\text { - Parliamen- } \\
\text { tary Inquiry }\end{array}$ & $\begin{array}{l}\text { - Eskom } \\
\text { - Department } \\
\text { of Public } \\
\text { Enterprises }\end{array}$ \\
\hline $\begin{array}{l}\text { Nugent } \\
\text { Commission } \\
\text { - SARS } \\
\text { Inquiry }\end{array}$ & $\begin{array}{l}\text { The Inquiry was } \\
\text { constituted on } \\
24 \text { May } 2018 \text { and } \\
\text { the final report } \\
\text { was released in } \\
\text { December } 2018 \text {. }\end{array}$ & $\begin{array}{l}\text { Commission of Inquiry into tax administration } \\
\text { and governance by South African Revenue } \\
\text { Service (SARS). Tom Moyane was fired based on } \\
\text { the interim report released in September } 2018 . \\
\text { The inquiry found that Moyane, with the help of } \\
\text { consultancy company Bain, had implemented } \\
\text { restructuring of the organisation, resulting in } \\
\text { gross mismanagement and erosion of SARS. } \\
\text { Moyane motivated the restructuring based on } \\
\text { the "rogue unit" narrative that has been the } \\
\text { subject of several other debunked investigations } \\
\text { and the subject of much litigation. }\end{array}$ & $\begin{array}{l}\text { - Judicial } \\
\text { Commission } \\
\text { of Inquiry } \\
\text { - Court cases } \\
\text { around the } \\
\text { "rogue unit" } \\
\text { narrative }\end{array}$ & $\begin{array}{l}\text { - SARS } \\
\text { (National } \\
\text { Treasury) }\end{array}$ \\
\hline
\end{tabular}




\begin{tabular}{|c|c|c|c|c|}
\hline $\begin{array}{l}\text { Case Study } \\
\text { in State } \\
\text { Capture }\end{array}$ & Status & Summary Description & $\begin{array}{l}\text { Investigation } \\
\text { Body / } \\
\text { Source of } \\
\text { Evidence }\end{array}$ & $\begin{array}{l}\text { Government } \\
\text { Entity } \\
\text { Implicated }\end{array}$ \\
\hline \multicolumn{5}{|c|}{ Scandals Connected to Jacob Zuma, Guptas, Other Key Networks and ANC Politics } \\
\hline \multicolumn{5}{|c|}{ State Capture of State-Owned Enterprises and Government Departments } \\
\hline $\begin{array}{l}\text { Commission } \\
\text { of Inquiry } \\
\text { into Public } \\
\text { Investment } \\
\text { Corporation } \\
\text { (PIC) }\end{array}$ & $\begin{array}{l}\text { In October } 2018 \text {, } \\
\text { the Commission } \\
\text { was constituted, } \\
\text { and the final report } \\
\text { was released in } \\
\text { March } 2020 .\end{array}$ & $\begin{array}{l}\text { Commission of Inquiry into allegations of } \\
\text { impropriety regarding Public Investment } \\
\text { Corporation (PIC). There were extensive hearings } \\
\text { on various 'dodgy' deals the PIC entered } \\
\text { into and details of political and executive } \\
\text { interference in the operations and decision- } \\
\text { making processes of the investment agency. }\end{array}$ & $\begin{array}{l}\text { - Judicial } \\
\text { Commission } \\
\text { of Inquiry }\end{array}$ & $\begin{array}{l}\text { - PIC (National } \\
\text { Treasury) }\end{array}$ \\
\hline $\begin{array}{l}\text { South African } \\
\text { Social } \\
\text { Security } \\
\text { Agency } \\
\text { (SASSA) }\end{array}$ & $\begin{array}{l}\text { Various } \\
\text { Constitutional Court } \\
\text { cases from } 2011 \\
\text { to } 2018 \text { resulted } \\
\text { in removal of CPS } \\
\text { as service provider } \\
\text { to SASSA. }\end{array}$ & $\begin{array}{l}\text { In 2014, South African Social Security Agency's } \\
\text { (SASSA) } 2012 \text { contract with CPS was found } \\
\text { to be irregular and invalid, however, due to the } \\
\text { importance of ensuring beneficiaries received } \\
\text { grants, CPS continued to be the service } \\
\text { providers until } 2018 \text {. Following a March } 2017 \\
\text { ruling, the Constitutional Court instituted a } \\
\text { Section } 38 \text { Inquiry into Minister Bathabile } \\
\text { Dlamini's personal liability for the narrowly } \\
\text { averted grant payment crisis. }\end{array}$ & $\begin{array}{l}\text { Primary } \\
\text { sources: } \\
\text { - AllPay court } \\
\text { case } \\
\text { - Black Sash } \\
\text { court case }\end{array}$ & - SASSA \\
\hline $\begin{array}{l}\text { South African } \\
\text { Airways (SAA) } \\
\text { and SAA } \\
\text { Technical }\end{array}$ & $\begin{array}{l}\text { Court case } \\
\text { to have Dudu } \\
\text { Myeni declared a } \\
\text { delinquent director } \\
\text { was launched } \\
\text { in } 2017 .\end{array}$ & $\begin{array}{l}\text { Court case was launched in } 2017 \text { by Outa and } \\
\text { the SAA Pilots' Association (SAAPA) to declare } \\
\text { Myeni a delinquent director in terms of the } \\
\text { Companies Act, based on her actions while she } \\
\text { was chairperson of the SAA Board. In 2020, the } \\
\text { High Court declared Myeni a delinquent director } \\
\text { for life. A significant amount of new evidence } \\
\text { also emerged through the Zondo Commission, } \\
\text { outlining how the operations at SAA were } \\
\text { undermined and how Myeni and others abused } \\
\text { their positions of authority. }\end{array}$ & $\begin{array}{l}\text { - Court } \\
\text { papers } \\
\text { - Zondo } \\
\text { Commission }\end{array}$ & $\begin{array}{l}\text { - SAA } \\
\text { - SAA Technical }\end{array}$ \\
\hline $\begin{array}{l}\text { Gupta Family } \\
\text { Naturalisation }\end{array}$ & $\begin{array}{l}\text { In June } 2017, \\
\text { Parliament directed } \\
4 \text { committees to } \\
\text { investigate state } \\
\text { capture. Final } \\
\text { report was tabled } \\
14 \text { March } 2019 .\end{array}$ & $\begin{array}{l}\text { Portfolio Committee on Home Affairs Inquiry into } \\
\text { the Gupta Family Naturalisation was established } \\
\text { in terms of the Parliamentary directive. Hearings } \\
\text { formally started on } 12 \text { September 2018. Final } \\
\text { report was tabled on } 14 \text { March 2019. Questions } \\
\text { were raised around contracts with Visa } \\
\text { Facilitation Services. This matter is ongoing as } \\
\text { of December } 2020 \text {. }\end{array}$ & $\begin{array}{l}\text { - Portfolio } \\
\text { Committee } \\
\text { on Home } \\
\text { Affairs }\end{array}$ & $\begin{array}{l}\text { - Department of } \\
\text { Home Affairs }\end{array}$ \\
\hline $\begin{array}{l}\text { Inquiry into } \\
\text { State Capture } \\
\text { related to } \\
\text { Gupta-owned } \\
\text { mines }\end{array}$ & $\begin{array}{l}\text { In June } 2017, \\
\text { Parliament directed } \\
4 \text { committees } \\
\text { to investigate } \\
\text { state capture. }\end{array}$ & $\begin{array}{l}\text { Though the Committee drafted a term of } \\
\text { reference for the Inquiry, the activities of holding } \\
\text { hearings and consolidating the evidence never } \\
\text { materialised beyond questions being put to then } \\
\text { Minister Zwane. }\end{array}$ & $\begin{array}{l}\text { - Portfolio } \\
\text { Committee } \\
\text { on Mineral } \\
\text { Resources }\end{array}$ & $\begin{array}{l}\text { - Department } \\
\text { of Mineral } \\
\text { Resources }\end{array}$ \\
\hline
\end{tabular}




\begin{tabular}{|c|c|c|c|c|}
\hline $\begin{array}{l}\text { Case Study } \\
\text { in State } \\
\text { Capture }\end{array}$ & Status & Summary Description & $\begin{array}{l}\text { Investigation } \\
\text { Body / } \\
\text { Source of } \\
\text { Evidence }\end{array}$ & $\begin{array}{l}\text { Government } \\
\text { Entity } \\
\text { Implicated }\end{array}$ \\
\hline \multicolumn{5}{|c|}{ Scandals Connected to Jacob Zuma, Guptas, Other Key Networks and ANC Politics } \\
\hline \multicolumn{5}{|c|}{ State Capture of State-Owned Enterprises and Government Departments } \\
\hline \multirow{3}{*}{$\begin{array}{l}\text { Various } \\
\text { investigations } \\
\text { relating to } \\
\text { State Capture } \\
\text { at Eskom }\end{array}$} & 2015 & $\begin{array}{l}\text { In 2015, Dentons produced an interim report } \\
\text { on their investigations into Status of Business } \\
\text { and Challenges at Eskom. Their investigation } \\
\text { was halted. }\end{array}$ & - Eskom & - Eskom \\
\hline & \multirow[t]{2}{*}{2017} & $\begin{array}{l}\text { In 2017, PricewaterhouseCoopers (PwC) was } \\
\text { appointed by National Treasury to investigate } \\
\text { Eskom's Coal Procurement Processes. Damning } \\
\text { findings were made in relation to Gupta-owned } \\
\text { Tegeta mine contracts and poor coal quality. }\end{array}$ & - Eskom & - Eskom \\
\hline & & $\begin{array}{l}\text { G9 was contracted by Eskom to investigate } \\
\text { the Trillian/McKinsey contracts. Interim report } \\
\text { presented to Board of Eskom in August } 2017 . \\
\text { The investigation remained incomplete, and } \\
\text { no report is available in the public domain. } \\
\text { Evidence from the investigation was presented } \\
\text { in the Parliamentary Inquiry into Eskom } \\
\text { State Capture. }\end{array}$ & $\begin{array}{l}\text { - National } \\
\text { Treasury }\end{array}$ & - Eskom \\
\hline $\begin{array}{l}\text { National } \\
\text { Treasury } \\
\text { Fundudzi } \\
\text { reports, } \\
\text { related to } \\
\text { Eskom and } \\
\text { Transnet }(x 3)\end{array}$ & $\begin{array}{l}\text { Final reports } \\
\text { compiled in } \\
\text { November } 2018 \\
\text { and released to } \\
\text { the public shortly } \\
\text { thereafter. }\end{array}$ & $\begin{array}{l}\text { Investigations requested by National Treasury } \\
\text { of alleged corruption at Transnet and Eskom. } \\
\text { The three reports focused on Eskom (general), } \\
\text { the contracts related to Trillian/McKinsey and } \\
\text { Transnet Locomotives. }\end{array}$ & $\begin{array}{l}\text { - National } \\
\text { Treasury } \\
\text { Fundudzi }\end{array}$ & $\begin{array}{l}\text { - Eskom } \\
\text { - Transnet }\end{array}$ \\
\hline \multirow[t]{2}{*}{$\begin{array}{l}\text { Transnet } \\
\text { Locomotive } \\
\text { Contracts }\end{array}$} & \multirow[t]{2}{*}{$\begin{array}{l}\text { Investigations } \\
\text { commenced in } \\
\text { December } 2017 \\
\text { and reports on } \\
\text { findings submitted } \\
\text { during } 2018 .\end{array}$} & $\begin{array}{l}\text { Werksmans Attorneys was appointed in } \\
\text { December } 2017 \text { to undertake an investigation } \\
\text { into the } 1064 \text { Transnet Locomotives } \\
\text { procurement process, however, the investigation } \\
\text { was halted. No report in the public domain. }\end{array}$ & - Werksmans & - Transnet \\
\hline & & $\begin{array}{l}\text { Mncedisi Ndlovu \& Sedumedi (MNS) Attorneys } \\
\text { was then appointed to investigate } 1064 \\
\text { locomotives procurement process. The report } \\
\text { is not in the public domain, but media indicates } \\
\text { that recommendations mirror the Werksmans' } \\
\text { findings and recommends that Molefe face } \\
\text { criminal charges. }\end{array}$ & $\begin{array}{l}\text { - Mncedisi } \\
\text { Ndlovu \& } \\
\text { Sedumedi }\end{array}$ & - Transnet \\
\hline $\begin{array}{l}\text { Inquiry into } \\
\text { State Capture } \\
\text { at Transnet } \\
\text { and Denel }\end{array}$ & $\begin{array}{l}\text { In June } 2017, \\
\text { Parliament directed } \\
4 \text { committees to } \\
\text { investigate state } \\
\text { capture. Committee } \\
\text { hearings were not } \\
\text { completed. }\end{array}$ & $\begin{array}{l}\text { A detailed information booklet was prepared } \\
\text { in relation to Transnet, however, hearings were } \\
\text { not held before the end of term of Parliament. } \\
\text { Following National elections in } 2019 \text {, it } \\
\text { was decided that outstanding Inquiries into } \\
\text { state capture be postponed indefinitely until } \\
\text { conclusion of the Zondo Commission. }\end{array}$ & $\begin{array}{l}\text { - Portfolio } \\
\text { Committee } \\
\text { on Public } \\
\text { Enterprises }\end{array}$ & $\begin{array}{l}\text { - Transnet } \\
\text { - Denel }\end{array}$ \\
\hline
\end{tabular}




\begin{tabular}{|c|c|c|c|c|}
\hline $\begin{array}{l}\text { Case Study } \\
\text { in State } \\
\text { Capture }\end{array}$ & Status & Summary Description & $\begin{array}{l}\text { Investigation } \\
\text { Body / } \\
\text { Source of } \\
\text { Evidence }\end{array}$ & $\begin{array}{l}\text { Government } \\
\text { Entity } \\
\text { Implicated }\end{array}$ \\
\hline \multicolumn{5}{|c|}{ Scandals Connected to Jacob Zuma, Guptas, Other Key Networks and ANC Politics } \\
\hline \multicolumn{5}{|c|}{ Law Enforcement and the Security Cluster } \\
\hline $\begin{array}{l}\text { Enquiry into } \\
\text { Jiba and } \\
\text { Mrwebi's } \\
\text { fitness to } \\
\text { hold office } \\
\text { at NPA }\end{array}$ & $\begin{array}{l}\text { Established in } \\
\text { November } 2018 . \\
\text { Report was issued } \\
\text { in April } 2019 .\end{array}$ & $\begin{array}{l}\text { Presidential Enquiry into the fitness to hold } \\
\text { office of suspended NPA senior advocates } \\
\text { Nomgcobo Jiba and Lawrence Mrwebi. NPA's } \\
\text { deputy head Jiba, and Mrwebi, the head of } \\
\text { the Specialised Commercial Crimes Unit, were } \\
\text { suspended in October } 2018 \text { by President Cyril } \\
\text { Ramaphosa. The Inquiry was headed by retired } \\
\text { Constitutional Court Justice Yvonne Mokgoro. } \\
\text { Jiba and Mrwebi were accused of improper } \\
\text { conduct in their handling of cases involving } \\
\text { former crime intelligence head Richard Mdluli, } \\
\text { as well as former KwaZulu-Natal Hawks boss } \\
\text { Johan Booysen. }\end{array}$ & $\begin{array}{c}\text { - Mokgoro } \\
\text { Enquiry }\end{array}$ & $\begin{array}{l}\text { - } \text { National } \\
\text { Prosecuting } \\
\text { Authority }\end{array}$ \\
\hline $\begin{array}{l}\text { High-Level } \\
\text { Review Panel } \\
\text { on the State } \\
\text { Security } \\
\text { Agency (SSA) }\end{array}$ & $\begin{array}{l}\text { Established in June } \\
2018 \text { and final } \\
\text { report was sent to } \\
\text { the President in } \\
\text { December } 2018 .\end{array}$ & $\begin{array}{l}\text { The High-Level Review Panel into the SSA } \\
\text { was established by President Ramaphosa in } \\
\text { June 2018. The key finding was a serious } \\
\text { politicisation and factionalisation of the } \\
\text { intelligence community over the past decade } \\
\text { or more. This resulted in "an almost complete } \\
\text { disregard for the Constitution, policy, legislation } \\
\text { and other prescripts, and [turned] our civilian } \\
\text { intelligence community into a private resource } \\
\text { to serve the political and personal interests of } \\
\text { particular individuals" (High-Level Review Panel } \\
\text { on the SSA, 2018, p. ii). }\end{array}$ & $\begin{array}{l}\text { - Review } \\
\text { Panel } \\
\text { established } \\
\text { by President } \\
\text { Ramaphosa }\end{array}$ & - SSA \\
\hline $\begin{array}{l}\text { Various court } \\
\text { cases against } \\
\text { persons } \\
\text { within law } \\
\text { enforcement }\end{array}$ & Ongoing. & $\begin{array}{l}\text { Though testimony and evidence have been } \\
\text { presented at the Zondo Commission, it is } \\
\text { understood that no definitive findings will be } \\
\text { made regarding the capture of law enforcement } \\
\text { under the Zuma administration. Since } 2012 \\
\text { onwards, there were several court cases } \\
\text { that were pursued against individuals in law } \\
\text { enforcement, all of which have been either } \\
\text { dismissed or withdrawn. Most noteworthy are } \\
\text { the cases involved, amongst others: Anwa } \\
\text { Dramat and Shadrack Sibiya of the Hawks } \\
\text { (and Robert McBride from Independent Police } \\
\text { Investigative Directorate [IPID]) for allegations } \\
\text { related to the "Zimbabwean rendition" matter; } \\
\text { Johan Booysen for alleged racketeering as part } \\
\text { of "Cato Manor hit squad"; and the various } \\
\text { senior officials accused of being part of the } \\
\text { "rogue" intelligence unit at SARS. Other court } \\
\text { cases that have provided significant evidence } \\
\text { indicating the capture of law enforcement relate } \\
\text { to the irregular appointed allies of the Shadow } \\
\text { State capture network or the irrational removal } \\
\text { of potential opponents holding senior positions } \\
\text { in law enforcement. Example is the irregular } \\
\text { removal of Mxolisi Nxasana as National Director } \\
\text { of Public Prosecutions (NDPP). }\end{array}$ & $\begin{array}{l}\text { - Various } \\
\text { court cases, } \\
\text { proceedings } \\
\text { in Parlia- } \\
\text { ment } \\
\text { - Zondo } \\
\text { Commission }\end{array}$ & $\begin{array}{l}\text { - NPA } \\
\text { - SAPS } \\
\text { - Hawks } \\
\text { - IPID }\end{array}$ \\
\hline
\end{tabular}




\begin{tabular}{|c|c|c|c|c|}
\hline $\begin{array}{l}\text { Case Study } \\
\text { in State } \\
\text { Capture }\end{array}$ & Status & Summary Description & $\begin{array}{l}\text { Investigation } \\
\text { Body / } \\
\text { Source of } \\
\text { Evidence }\end{array}$ & $\begin{array}{l}\text { Government } \\
\text { Entity } \\
\text { Implicated }\end{array}$ \\
\hline \multicolumn{5}{|c|}{ Scandals Connected to Jacob Zuma, Guptas, Other Key Networks and ANC Politics } \\
\hline \multicolumn{5}{|c|}{ Investigations concerning Private Sector } \\
\hline $\begin{array}{l}\text { Budlender } \\
\text { report on } \\
\text { Trillian }\end{array}$ & $\begin{array}{l}\text { Released in } \\
\text { June } 2017 .\end{array}$ & $\begin{array}{l}\text { Trillian Holdings Board appointed Geoff } \\
\text { Budlender SC to undertake investigations into } \\
\text { State Capture allegations at Trillian Capital. } \\
\text { Detailed accounts from whistle-blowers } \\
\text { highlighted how information was withheld by } \\
\text { senior management at Trillian. }\end{array}$ & - Trillion & - Eskom \\
\hline $\begin{array}{l}\text { Collapse of } \\
\text { VBS Mutual } \\
\text { Bank }\end{array}$ & $\begin{array}{l}\text { Investigation } \\
\text { launched in } \\
\text { April } 2018 \text { and } \\
\text { the report was } \\
\text { released in } \\
\text { October } 2018 .\end{array}$ & $\begin{array}{l}\text { Minister of Finance placed VBS under } \\
\text { curatorship with effect from } 11 \text { March 2018. In } \\
\text { April 2018, the Deputy Governor of the South } \\
\text { African Reserve Bank instituted an investigation } \\
\text { into VBS. The outcomes of the investigation } \\
\text { showed blatant fraud and corruption by senior } \\
\text { executives/Board and how they extracted } \\
\text { money from the bank. Municipal funds were } \\
\text { illegally deposited with VBS (senior ANC and } \\
\text { EFF politicians have been implicated). }\end{array}$ & $\begin{array}{l}\text { - SARB } \\
\text { investiga- } \\
\text { tion report } \\
\text { VBS Mutual } \\
\text { Bank - The } \\
\text { Great Bank } \\
\text { Heist }\end{array}$ & $\begin{array}{l}\text { - Several } \\
\text { Provincial and } \\
\text { Municipal } \\
\text { Officials } \\
\text { (Limpopo } \\
\text { Government) } \\
\text { - SOEs } \\
\text { (particularly } \\
\text { PRASA) }\end{array}$ \\
\hline $\begin{array}{l}\text { SA Institute } \\
\text { of Chartered } \\
\text { Accountants' } \\
\text { (SAICA) } \\
\text { investigation } \\
\text { into KPMG }\end{array}$ & $\begin{array}{l}\text { Final report was } \\
\text { handed to SAICA in } \\
\text { December } 2018 .\end{array}$ & $\begin{array}{l}\text { SA Institute of Chartered Accountants (SAICA) } \\
\text { established an Inquiry to investigate state } \\
\text { capture related allegations of misconduct of its } \\
\text { members who worked for KPMG. The Inquiry } \\
\text { chaired by advocate Dumisa Ntsebeza held } \\
\text { public hearings and handed its final report to } \\
\text { SAICA in December 2018. Indications are that } \\
\text { the final report will not be made public until all } \\
\text { investigations and disciplinary hearings have } \\
\text { been finalised. }\end{array}$ & - SAICA & - Guptas \\
\hline Bell Pottinger & $\begin{array}{l}2017 \text { investigation } \\
\text { by PRCA. }\end{array}$ & $\begin{array}{l}\text { In 2016, the Guptas appointed British PR } \\
\text { company, Bell Pottinger, who developed and } \\
\text { promoted a campaign that underpinned the RET } \\
\text { and WMC narratives. In 2017, there was an } \\
\text { independent law firm review by Herbert Smith } \\
\text { Freehills resulting in Bell Pottinger's expulsion } \\
\text { from the Public Relations and Communications } \\
\text { Association (PRCA). }\end{array}$ & $\begin{array}{l}\text { - PRCA } \\
\text { - GuptaLeaks } \\
\text { - Ongoing } \\
\text { research } \\
\text { on disinfor- } \\
\text { mation }\end{array}$ & - Guptas \\
\hline
\end{tabular}

